\title{
The Trematode Parasites of Lophius piscatorius (Angler Fish) from the Aegean Sea
}

Ege Denizi’nden Yakalanan Lophius piscatorius'ların (Fener Balığı) Trematod Parazitleri

\section{Yahya Tepe}

Department of Biology, Atatürk University School of Medicine, Erzurum, Turkey

\section{ABSTRACT}

Objective: There is no study on the trematode parasites of Lophius piscatorius. The aim of this study is to address the lack of knowledge about the parasites of angler fish from the coasts of Turkish seas.

Methods: Frozen individuals of $L$. piscatorius from the coasts of Izmir were brought to Ataturk University, and their visceral organs were parasitologically investigated. Parasites were fixed with AFA (Acetic acid-Formaline-Alcohol) fixative and permanently mounted with Canada balsam.

Results: Two digenean species were recorded: Prosorhynchoides gracilescens (Bucephalidae), which is commonly found in L. piscatorius, and Aphallus tubarium (Cryptogonimidae), which is rarely harbored in L. piscatorius.

Conclusion: Both species comprise the newly discovered parasite fauna of Turkey.

Keywords: Aegean Sea, Bucephalidae, Cryptogonimidae, Lophius piscatorius, Turkey

Received: 24.03.2016

Accepted: 08.12.2016

\section{Öz}

Amaç: Türkiye'de daha önce Lophius piscatorius'un trematod parazitleri araştırılmamıştır. Bu çalışmanın amacı Türkiye kıyılarında yaşayan fener balıklarının parazit faunası hakkındaki bilgi eksikliğini gidermektir.

Yöntemler: İzmir kıyılarında yakalanmış olan L.piscatorius'lar dondurulmuş olarak Atatürk Üniversitesi'ne getirilmiş ve balıkların iç organlarındaki parazitler araştııımıştır. Tespit edilen parazitler AFA (Asetik asit-Formalin-Alkol) fiksatifiyle tespit edilip, Kanada balsamılla kalıcı preparatları yapılmıştır.

Bulgular: İncelenen balıklardan iki digenea türü tespit edilmiştir. Bunlar L. piscatorius'ta sıkça rastlanan Prosorhynchoides gracilescens (Bucephalidae) ve L.piscatorius'ta nadiren rastlanan Aphallus tubarium (Cryptogonimidae)'dur.

Sonuç: Her iki tür de Türkiye parazit faunası için yeni kayıttır.

Anahtar Kelimeler: Ege Denizi, Bucephalidae, Cryptogonimidae, Lophius piscatorius, Türkiye

Geliş Tarihi: 24.03.2016

Kabul Tarihi: 08.12.2016

\section{INTRODUCTION}

Majority of the animals live free and the others live together. The association between animals can be divided into two groups: homogenetic and heterogenetic. The association between individuals of the same species is homogenetic, such as ants and bees, and between those of different species is heterogenetic. Parasitism is a lifestyle of heterogenetic association that is much more complex than that of homogenetic association (1).
In general, the parasitic way of the life is successful and found in nearly every phylum of animals from protists to arthropods and chordates as well as in many plant groups. Humans, for example, can be infected with more than hundred types of parasites. It is almost impossible to find animals not infected by even a single parasite on or within it. Organisms that are not parasites are usually hosts (2).

The marine fish fauna of Turkey consists of 512 species (3). Only 84 marine fish species of Turkey have been parasitologically studied and 161 metazoan parasites were found (4).

Address for Correspondence / Yazışma Adresi: Yahya Tepe E.mail: tepeyahya@hotmail.com DOI: 10.5152/tpd.2017.4806

CCopyright 2017 Turkish Society for Parasitology - Available online at www.tparazitolderg.org

CTelif hakkı 2017 Türkiye Parazitoloji Derneği - Makale metnine www.tparazitolderg.org web sayfasından ulaşılabilir. 
Angler fish, a common carnivorous and demersal fish of the Black Sea; Mediterranean Sea; coasts of Europe, Africa, and Northern America; Atlantic Ocean; Arctic Ocean; and Baltic Sea but not the the Pacific and Indian Oceans is one of the important species of the marine fish fauna of Turkey (5). Although there are many papers on parasites, mainly on Protozoa, Monogenea, and Crustacea, of the marine fishes from Turkey, only two studies by Öktener and Trilles (6) and Akmirza (7) mentioned regarding one crustacean and nematod species of $L$. piscatorius, respectively.

The aim of this paper is to contribute to the research on trematod parasite fauna of marine fishes of Turkey.

\section{METHODS}

A total nine $L$. piscatorius samples collected by the fishermen from the coasts of the Aegean Sea (Izmir) were brought to the Parasitology Research Laboratory of Ataturk University Science Faculty in April 2014. The alimentary organs, livers, and gallbladders of the fishes were taken out and put into petri dishes filled with $1 \%$ saline water after the dissection. The detected parasites were fixed with alcohol-formalin-acetic acid (AFA), dyed with Mayer's carmalum, and mounted with Canada balsam, according to the study by Pritchard and Kruse (8). Identification of the parasites was executed according to studies by Dawes (9), Dawes (10), Yamaguti (11), and Skrjabin (12). Author declared that the study was conducted according to the principles of the World Medical Association Declaration of Helsinki "Ethical Principles for Medical Research Involving Human Subjects" (amended in October 2013).

\section{RESULTS}

Family: Cryptogonimidae Ward, 1917

Aphallus tubarium (Rudolphi, 1819) Poche, 1926

Synonyms: Distoma tubarium (Rudolphi, 1819); Distoma fuscescens (Rudolphi, 1819); Distomum (Cryptogonimus) tubarium (Rudolphi, 1819 and Nicoll, 1915); Acanthochasmus inermis (Stossich, 1905); Acanthostomum inermis (Stossich, 1905 and Yamaguti, 1958); Aphallus fuscescens (Rudolphi, 1819 and Yamaguti, 1971).

The body is long and slightly wide at the ventral sucker level. The tegument is spinous. The oral sucker is a little larger than the ventral one. The pharynx is slightly rectangular, and the esophagus is longer than the prepharynx. The intestinal ceca extend to the posterior end of the body. The pretesticular ovary is threelobed, and the uterus extends to the posterior end of the body. The eggs are small and nonfilamentous. The vitellin glands are globular and located between nearly the middle of the body and the posterior of the hind testis. The anterior testis is smaller than the posterior one (Figure 1) (Table 1).

Family: Bucephalidae

\section{Prosorhynchoides gracilescens (Rudolphi, 1819)}

Synonyms: Bucephaloides gracilescens (Rudolphi, 1819); Bucephalopsis gracilescens (Rudolphi, 1819); Prosorhynchus gracilescens (Rudolphi, 1819).
The shape of the body, broader anteriorly, is elongated and oval. The oral sucker is larger than the pharynx. The intestine is simple and sac-like. The genital pore is at the posterior end of the body. The testes are slightly globular, and the cirrus sac is long and located at posterior end of the body. The pretesticular ovary is spherical. The vitellin follicles are few in number, globular, slightly larger, and located at the anterior half of the body. The eggs are operculate, small, and ovoid (Figure 1) (Table 2).

\section{DISCUSSION}

The cosmopolitan family Cryptogonimidae Ward, 1917, includes a large number of species from marine and freshwater fishes to snakes and crocodiles (13). The metacercariae of Cryptogonimids encyst in the tissues of fishes The adults are found in the gut sometimes in the other organs of freshwater and marine fishes, occasionally in amphibians and reptiles (14).

A. tubarium was recorded previously in Dentex dentex; L. piscatorius; Sciaena umbra; Gobius ophiocephalus; Sparus pagrus; Syngnathus typhle; Trachurus trachurus; and Umbrina cirrhosa $(13,15-24)$.

In light of the literature, it is clear that $A$. tubarium can be found in various fish species of the Atlantic Ocean, Mediterranean Sea, Aegean Sea, and Black Sea, whereas it has not been found in the fish species of Turkish seas.

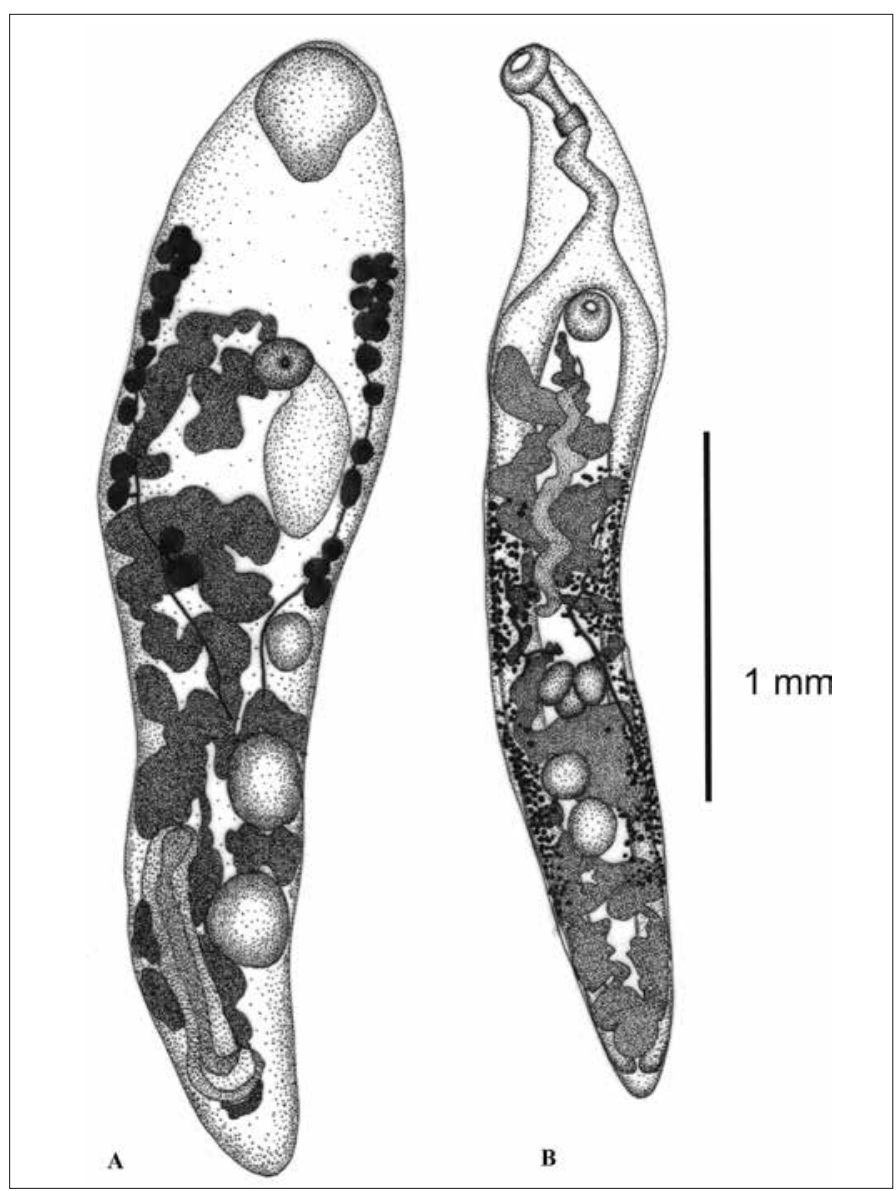

Figure 1. a, b. (a) Prosorhynchoides gracilescens, (b) Aphallus tubarium 
Table 1. The measurements of Aphallus tubarium ( $\mu \mathrm{m})$ [min-max (average)]

\begin{tabular}{|c|c|c|c|}
\hline $\begin{array}{l}\text { Aphallus tubarium } \\
\text { (Rudolphi, 1819) Poche, } 1926\end{array}$ & $\begin{array}{l}\text { Lophius piscatorius } \\
\text { Izmir, Aegean Sea } \\
\text { (present study) }\end{array}$ & $\begin{array}{c}\text { Dentex dentex } \\
\text { Scandola, Corsica } \\
\text { (13) }\end{array}$ & $\begin{array}{c}\text { Syngnathus typhle } \\
\text { Black Sea } \\
(22)\end{array}$ \\
\hline Length & 1990-4001 (2947) & 2425-4797 (2894) & $2553-3243$ \\
\hline Width & $264-528(381)$ & $341-682(519)$ & 552 \\
\hline Oral Sucker Length & $105-145$ (122) & $124-217(186)$ & $152-179$ \\
\hline Oral Sucker Width & $121-162(141)$ & $152-250(201)$ & 193-221 \\
\hline Ventral Sucker Length & 113-162 (130) & 130-234 (187) & 152 \\
\hline Ventral Sucker Width & $105-145$ (120) & $124-234(191)$ & 166 \\
\hline Pharynx Length & 73-105 (88) & $104-152$ (124) & 97 \\
\hline Pharynx Width & $65-81(74)$ & $76-130(103)$ & 110 \\
\hline Prepharynx & $121-242(178)$ & $39-108(81)$ & Data not reported \\
\hline Esophagus & $267-687(492)$ & $130-423(260)$ & Data not reported \\
\hline Anterior Testis Length & $81-170(117)$ & $160-293(213)$ & $317-386$ \\
\hline Anterior Testis Width & $73-202$ (122) & $149-320(237)$ & $290-317$ \\
\hline Posterior Testis Length & 73-218 (137) & $197-373(249)$ & $345-400$ \\
\hline Posterior Testis Width & $73-218(140)$ & $160-320(243)$ & $290-386$ \\
\hline Ovary Length & $105-210(157)$ & $133-229(191)$ & $207-276$ \\
\hline Ovary Width & $81-242(146)$ & $160-320(250)$ & $207-386$ \\
\hline Egg Length & $12-20(17)$ & $20-24(22)$ & $19-22$ \\
\hline Egg Width & 8-10 (9) & $7-13(9)$ & $8-11$ \\
\hline
\end{tabular}

Table 2. Some morphometric measures of Prosorhynchoides gracilescens ( $\mu \mathrm{m})$ [min-max (average)]

\begin{tabular}{|c|c|c|c|}
\hline \multirow[b]{2}{*}{$\begin{array}{l}\text { Aphallus tubarium } \\
\text { (Rudolphi, 1819) Poche, } 1926\end{array}$} & \multicolumn{3}{|c|}{ Lophius piscatorius } \\
\hline & $\begin{array}{l}\text { Izmir, Aegean Sea } \\
\text { (present study) }\end{array}$ & $\begin{array}{l}\text { Gulf of Marseille } \\
\text { (27) }\end{array}$ & $\begin{array}{l}\text { Off England } \\
\text { (27) }\end{array}$ \\
\hline Width & 467-995 (739) & $537-900(702)$ & $355-553(430)$ \\
\hline Oral Sucker Length & $203-406$ (292) & $356-425(385)$ & $191-279(244)$ \\
\hline Pharynx Width & $122-183$ (159) & $147-235$ (179) & $118-165$ (138) \\
\hline Intestinal Cecum Length & $345-630(470)$ & $254-483(334)$ & $154-358(284)$ \\
\hline Intestinal Cecum Width & $142-284(232)$ & $160-330(224)$ & 114-182 (150) \\
\hline Anterior Testis Length & $223-366(276)$ & $254-380(312)$ & $199-288(230)$ \\
\hline Ovary Length & $122-244$ (191) & $178-273(212)$ & $122-224$ (169) \\
\hline Ovary Width & $122-223(166)$ & $133-210(179)$ & 95-197 (123) \\
\hline Cirrus-Sac Length & 731-1198 (905) & 584-1232 (942) & $500-635$ (574) \\
\hline Cirrus-Sac Width & $122-223(166)$ & $143-235$ (186) & 93-154 (117) \\
\hline Egg Length & $20-24(23)$ & $19-22(20,8)$ & $19-22(21.1)$ \\
\hline Egg Width & $14-18(16)$ & $15-17(16.3)$ & $14-17(16.1)$ \\
\hline
\end{tabular}


Table 3. Parasite numbers of Lophius piscatorius

\begin{tabular}{|r|c|c|c|c|c|c|c|c|c|c|c|c|}
\hline Host Number & $\mathbf{1}$ & $\mathbf{2}$ & $\mathbf{3}$ & $\mathbf{4}$ & $\mathbf{5}$ & $\mathbf{6}$ & $\mathbf{7}$ & $\mathbf{8}$ & $\mathbf{9}$ & TPN & $\%$ & FREE \\
\hline Aphallus tubarium & - & - & 7 & 9 & 2 & - & - & 9 & - & 27 & 44 & \\
\hline $\begin{array}{l}\text { Prosorhynchoides } \\
\text { grasilescens }\end{array}$ & - & - & - & 2 & - & 3 & 7 & 2 & - & 14 & 44 & 33 \\
& $\begin{array}{l}\text { TPN: total parasite number; \%: } \\
\text { fishes }\end{array}$ \\
\hline
\end{tabular}

Table 4. The parasites of Lophius piscatorius from various localities

\begin{tabular}{|c|c|c|}
\hline $\begin{array}{l}\text { PARASITE } \\
\text { DIGENEA }\end{array}$ & LOCALITY & AUTHOR \\
\hline \multirow[t]{2}{*}{ Aphallus tubarium } & France & (39) \\
\hline & Greece & (19) \\
\hline Prosorhynchoides borealis & Northeast Atlantic & (27) \\
\hline \multirow[t]{9}{*}{ P. gracilescens } & England & (9), (10), (29), (31), (32), (33) \\
\hline & France & (39), (27) \\
\hline & Germany & $(15),(28),(40)$ \\
\hline & Icelandic Waters & (35), (41), (42) \\
\hline & Irish Sea & (34), \\
\hline & Italy & $(16),(30)$ \\
\hline & North Sea & (36) \\
\hline & Ukraine & $(21)$ \\
\hline & West Africa & $(43)$ \\
\hline Prosorhynchus aculeatus & France & (39) \\
\hline P. crucibulum & England & $(10),(33)$ \\
\hline Derogenes latus & France & (39) \\
\hline \multirow[t]{2}{*}{ D. varicus } & England & (10), (32), (33) \\
\hline & Icelandic Waters & $(35)$ \\
\hline Dinosoma sp. & France & (39) \\
\hline D. lophiomi & $\begin{array}{l}\text { Western } \\
\text { Mediterranean }\end{array}$ & (44) \\
\hline \multirow[t]{2}{*}{ Distomum cesticillus } & Germany & $(40)$ \\
\hline & Italy & (30) \\
\hline Di. hystrix & Germany & (40) \\
\hline Ectenurus lepidus & England & $(10)$ \\
\hline Gonocerca crassa & USA & (45) \\
\hline Hemiurus communis & England & (10), (32), (33) \\
\hline Lecithaster gibbosus & Icelandic Waters & (35) \\
\hline Lecithochirium fusiforme & France & (39) \\
\hline L. grandiporum & $\begin{array}{l}\text { Western } \\
\text { Mediterranean }\end{array}$ & (46) \\
\hline L. musculus & France & (39) \\
\hline L. physcon & England & (10) \\
\hline L. rufoviride & England & (10), (32), (33) \\
\hline L. excisum & England & (10) \\
\hline Metadena brotulae & USA & (10) \\
\hline Otodistomum sp. & Icelandic Waters & (35) \\
\hline
\end{tabular}

Table 4. The parasites of Lophius piscatorius from various localities (continued)

\begin{tabular}{|c|c|c|}
\hline $\begin{array}{l}\text { PARASITE } \\
\text { DIGENEA }\end{array}$ & LOCALITY & AUTHOR \\
\hline O. veliporum (larvae) & England & $(10)$ \\
\hline Stephanostomum sp. & Icelandic Waters & (35) \\
\hline S. baccatum (larvae) & England & $(10)$ \\
\hline S. caducum & England & (10) \\
\hline \multirow[t]{5}{*}{ S. cesticillum } & England & $(10)$ \\
\hline & Egypt & (47) \\
\hline & France & (39) \\
\hline & Italy & $(20)$ \\
\hline & $\begin{array}{l}\text { Western } \\
\text { Mediterranean }\end{array}$ & $(48)$ \\
\hline \multirow[t]{2}{*}{ Steringophorus furciger } & Icelandic Waters & (35) \\
\hline & England & $(10)$ \\
\hline Sterrhurus floridensis & USA & $(45)$ \\
\hline S. fusiforme & England & $(10),(33)$ \\
\hline S. grandiporus & England & $(10)$ \\
\hline S. musculus & England & (10) \\
\hline \multirow{2}{*}{$\begin{array}{l}\text { Synaptobothrium } \\
\text { caudiporum }\end{array}$} & England & (10), (32) \\
\hline & France & $(39)$ \\
\hline Zoogonoides viviparus & Icelandic Waters & (35) \\
\hline \multicolumn{3}{|l|}{ CESTODA } \\
\hline Bothrioceplialus lophii & Germany & (40) \\
\hline Grillotia sp. & Icelandic Waters & (35) \\
\hline $\begin{array}{l}\text { Rhynchobothrium } \\
\text { crassiceps }\end{array}$ & Germany & $(40)$ \\
\hline R. palcaceum & Germany & $(40)$ \\
\hline R. tennicolle & Germany & $(40)$ \\
\hline R. erinaceus & Germany & $(40)$ \\
\hline Scolex polymorphus & Germany & $(40)$ \\
\hline S. lophii piscatorii & Germany & $(40)$ \\
\hline Tetraphyllid plerocercoids & Icelandic Waters & (35) \\
\hline $\begin{array}{l}\text { Tetrarhynchus lophii } \\
\text { piscatorii }\end{array}$ & Germany & $(40)$ \\
\hline \multicolumn{3}{|l|}{ NEMATODA } \\
\hline Agamonema capsularia & Germany & $(40)$ \\
\hline A. commune & Germany & $(40)$ \\
\hline A. lophii piscatorii & Germany & (40) \\
\hline Anisakis simplex & Icelandic Waters & (35) \\
\hline Ascaris angulata & Germany & (40) \\
\hline A. incvescens & Germany & $(40)$ \\
\hline A. rigida & Germany & $(40)$ \\
\hline \multirow[t]{2}{*}{ Contracaecum clavatum } & England & $(33)$ \\
\hline & Italy & $(20)$ \\
\hline Capillaria sp. & Icelandic Waters & (35) \\
\hline Dikentrocephalus crinalis & Germany & $(40)$ \\
\hline
\end{tabular}


Table 4. The parasites of Lophius piscatorius from various localities (continued)

\begin{tabular}{|l|l|l|}
\hline $\begin{array}{l}\text { PARASITE } \\
\text { DIGENEA }\end{array}$ & LOCALITY & \\
\hline Hysterothylacium sp. & Icelandic Waters & $(35)$ \\
\hline H. aduncum & Icelandic Waters & $(35)$ \\
\hline & Turkey & $(7)$ \\
\hline H. rigidum & England & $(33)$ \\
\hline & Icelandic Waters & $(35)$ \\
\hline Cucullanus hians & England & $(33)$ \\
\hline Spinitectus sp. & Icelandic Waters & $(35)$ \\
\hline Phocascaris sp. & Icelandic Waters & $(35)$ \\
\hline Pseudoterranova decipiens & Icelandic Waters & $(35)$ \\
\hline ACANTHOCEPHALA & & \\
\hline Echinorhynchus acus & Germany & $(40)$ \\
\hline E. casculosus & Germany & $(40)$ \\
\hline E. gadi & Icelandic Waters & $(35)$ \\
\hline E. globosus & USA & $(49)$ \\
\hline E. propinquus & Italy & $(17)$ \\
\hline ANNELIDA-HIRUDINEA & & \\
\hline Calliobdella lophii & England & $(50)$ \\
\hline & $\begin{array}{l}\text { Norway To } \\
\text { Mediterranean }\end{array}$ & $(51)$ \\
\hline $\begin{array}{l}\text { ARTHROPODA- } \\
\text { CRUSTACEA }\end{array}$ & & $(52)$ \\
\hline Bomolochus attenuates & Panama & $(6)$ \\
\hline Chondracanthus lophii & Turkey & \\
\hline & & \\
\hline
\end{tabular}

The tegument of $A$. tubarium is spinous, but the tegument of the parasite we mounted is not covered with spines because the fish material was frozen and spines are very easily lost in frozen and poorly fixed materials (14). The width of the samples and the measures of the suckers, pharynx, testis, and ovary are smaller and the prepharynx and esophagus are longer than the measures of the $A$. tubarium described by Bartoli and Bray (13) and Kornychuk and Gaevskaya (22). The variation of the measurements can be due to the host difference. A. tubarium has been recorded from Turkey for the first time.

Bucephalids especially found in the gut and intestine, occasionally in the body cavities and tissues of the teleost fishes, rarely found in amphibians $(14,25)$. Prosorhynchoides is a cosmopolitan parasite that lives in marine and some freshwater fishes (26). P. gracilescens (Rudolphi, 1819) is a common intestinal parasite of the angler fish L. piscatorius in European marine waters (27).

P. gracilescens was previously recorded in L. piscatorius; Sarda sp. S. sarda Scomber sp.; Gadus morhua and Merlangius merlangus euxinus and Belone belone (9,10, 15, 16, 19, 21, 28-37).

P. gracilescens that is generally found in L. piscatorius and occasionally in various fish species of the European coasts of the Atlantic Ocean, Mediterranean Sea, Aegean Sea, and Black Sea has not been discovered in the Turkey seas.
The morphometric measures are consistent with those reported by Bartoli et al. (27). P. gracilescens has been recorded for the first time in the parasitic fauna of the marine fishes of Turkey.

\section{CONCLUSION}

We investigated nine L. piscatorius samples and noted that $33 \%$ of the fishes were not infected with any trematode. Infection rates of both $P$. gracilescens and A. tubarium are 44\% (Table 3). We found neither nematode nor any other parasite groups except digenean parasites in L. piscatorius. In light of the literature, it is obvious that a lot of parasite taxa were found in L. piscatorius of various seas of the world (38-52) (Table 4). Consequently, parasites of the angler fish of Turkish seas must be comprehensively studied.

Ethics Committee Approval: Author declared that the study was conducted according to the principles of the World Medical Association Declaration of Helsinki "Ethical Principles for Medical Research Involving Human Subjects" (amended in October 2013).

Informed Consent: Not required in this study

Peer-review: Externally peer-reviewed.

Acknowledgements: The author would like to thank Dr. R.A. Bray from the NHM of London for his help on verification of the descriptions.

Conflict of Interest: No conflict of interest was declared by the authors.

Financial Disclosure: The authors declared that this study has received no financial support

Etik Komite Onayı: Yazar çalışmanın World Medical Association Declaration of Helsinki "Ethical Principles for Medical Research Involving Human Subjects", (amended in October 2013) prensiplerine uygun olarak yapıldığını beyan etmiştir.

Hasta Onamı: Bu çalışma için hasta onamına gerek yoktur.

Hakem Değerlendirmesi: Dış Bağımsız.

Teşekkür: Yazar, Londra Natural History Museum'da görevli olan Dr. R.A. Bray'a teşhislerin doğrulanmasındaki yardımlarından dolayı teşekkür eder.

Çıkar Çatışması: Yazarlar çıkar çatışması bildirmemişlerdir.

Finansal Destek: Yazarlar bu çalışma için finansal destek almadıklarını beyan etmişlerdir.

\section{REFERENCES}

1. Smyth JD. Introduction to Animal Parasitology. Third Edition ed: Cambridge Universty Press; 1994. 549 p.

2. Schmidt GD, Roberts LS. Foundations of Parasitology. 8. ed: McGraw-Hill, a business unit of The McGraw-Hill Companies, Inc., 1221 Avenue of the Americas, New York, NY 10020.; 2009.

3. Bilecenoğlu M, Kaya M, Cihangir B, Çiçek E. An updated checklist of the marine fishes of Turkey. Turk J Zool 2014; 38: 901-29. [CrossRef]

4. Öktener A. An updated checklist of parasitic helminths of marine fish from Turkey. Transylv Rev Syst Ecol Res. 2014; 16: 55-96. [CrossRef]

5. Slastenenko E. Karadeniz Havzası Balıkları. İstanbul: 1955-1956.

6. Öktener A, Trilles JP. three new parasitic copepod species for the parasite fauna of marine fishes of Turkey. J Black Sea/ Medit Environ 2004; 10: 71-80.

7. Akmirza A. Parasitic nematodes of fish in the coastal waters of Gökçeada. Turkiye Parazitol Derg 2013; 37: 199-202. [CrossRef]

8. Pritchard MH, Kruse GO. The Collection and Preservation of Animal Parasites. Technical Bulletin No. 1. The Harold W. Manter Laboratory, University of Nebraska Press 1982. 
9. Dawes B. The Trematoda with Special Reference to British and other European Forms: Cambridge Univ. Press; 1946.

10. Dawes B. The Trematoda of British fishes. London: Ray Society 1947. p.364. [CrossRef]

11. Yamaguti S. Systema Helminthum: Digenetic Trematodes of Vertebrates-Part I: Interscience Publications, N. Y; 1958.

12. Skrjabin Kl. Trematody Zhivotnyh i Cheloveka (Trematodes of Animals and Man). Izdatel'stvo Akademii Nauk SSSR, Moscow-Leningrad 1962.

13. Bartoli P, Bray RA. Redescriptions of two cryptogonimid digeneans from the fish Dentex dentex (L., 1758) (Sparidae) in the Mediterranean Sea. Syst Parasitol 1987; 10: 117-27. [CrossRef]

14. Gibson DI. Trematoda in L. Margolis and Z. Kabata (ed) Guide to the Parasites of Fishes of Canada Part IV Can. Spec. Publ. Fish Aquat. Sci; 1996.

15. Rudolphi CA. Entozoorum Synopsis Cui Accedunt Mantissa Duplex et Indices Locupletissimi. Berolini. Sumtibus Agustini Rücker 1819. p.811. [CrossRef]

16. Molin R. Nuovi myzelmintha raccolti ed esaminati. Sitzungsbericht der Akademie der Wissenschaften Mathematisch. Naturwissenschaftlich Classe Wien 1859; 37: 818-54.

17. Stossich M. Brani di elmintologia tergestina. Serie prima. Bolletino della Societa Adriatica di Scienze Naturali in Trieste 1885; 9: 156-67.

18. Stossich M. Note distomologische. Bolletino della Societa Adriatica di Scienze Naturali in Trieste 1905; 22: 211-27.

19. Papoutsoglou SE. Metazoan parasites of fishes from Soronicos Gulf Athens-Greece. Thalassographica 1976; 1: 69-102.

20. Jardas I, Hristovski N. A new contribution to the knowledge of helminth parasite fauna of fishes from the channels between the Mid-Dalmatian Islands, Adriatic Sea. Acta Adriat 1985; 26: 145-64.

21. Gaevskaya AV, Korniychuk YM. Parasites Organisms as a Component of Ecosystems of the Black Sea Near-Shore Zone of Crimea. In: Eremeev V, Gaevskaya A, editors. Modern condition of biologicala diversity in nearshore zone of Crimea (the Black Sea sector). NAS Ukraine Institute of Biology of the Southern Seas. Sevastopol: EKOSI- Gidrophizika2003. p. 425-90.

22. Kornychuk YM, Gaevskaya AV. The first record of Aphallus tubarium (Trematoda, Cryptogonimidae) in the Black Sea. Vestnik Zoologii 2004; 38: 79-80

23. Monticelli FS. Studii sui Trematodi endoparassiti. Primo contribute di osservazioni sui Distomidi. Zoologische Jahrbücher, Supplementheft 1893; 3: 229.

24. Maclaren N. Report on occupation of the table during March and April 1902. b. On trematodes and cestodes parasitic in fishes. Report on the seventy-second meeting of the British Association for the Advancement of Science held at Belfast in September 1902. 1903: $260-2$

25. Schell SC. The Trematodes - How to Know the Trematodes: Win. C. Brown Company; 1970.

26. Gibson DI, Jones A, Bray RA. Keys To the Trematoda: CAB International, Wallingford; 2002.

27. Bartoli P, Gibson DI, Bray RA. Prosorhynchoides gracilescens (Rudolphi, 1819) (Digenea: Bucephalidae) from Lophius piscatorius $L$. is a species complex: a redescription of this species (sensu stricto) from the western Mediterranean and the description of $\mathrm{P}$. borealis $\mathrm{n}$. sp. from the northern North-East Atlantic. Syst Parasitol 2006; 63: 20321. [CrossRef]

28. Wagener GR. Enthelminthica. No. III. Ueber eine Distomengattung Gasterostoma v. Siebold. Archiv für Anatomie, Physiologie und Wissenschaftliche Medicin 1852: 555-69.

29. Cobbold TS. XII. Observations on Entozoa, with notices of several species, including an account of two experiments in regards to the breeding of Taenia serrata and T. cucumerina Trans Linn Soc Lond. 1858; 22: 155-72. [CrossRef]

30. Stossich M. Brani di elminthologia tergestina. Serie settima. Bolletino della Societa`Adriatica di Scienze Naturali in Trieste. 1890; 12: 39-47.
31. Nicoll W. A contribution towards a knowledge of the entozoa of British marine fishes. Part II. Ann Mag Nat Hist 1909; 8: 1-25. [CrossRef]

32. Nicoll W. The Trematodes parasites of fishes from the English Channel. J Mar Biol Assoc UK 1914; 10: 466-505. [CrossRef]

33. Baylis $\mathrm{H}$, Jones I. Some records of the parasitic worms from marine fishes at Plymouth. J Mar Biol Assoc UK. 1933; 18: 627-34. [CrossRef]

34. Halton DW, Johnston BR. Occurrence and infectivity of Bucephaloides gracilescens (Trematoda: Bucephalidae) in angler fish from the Irish Sea. Ir Nat J 1982; 20: 526-31.

35. Eydal M, Olafsdottir D. Intestinal Macroparasites In Anglerfish (Lophius piscatorius L.) From Icelandic Waters. Bull Scand Soc Parasitol 2002-2003; 12-13: 60-8.

36. Olson PD, Cribb TH, Tkach W, Bray RA, J Littlewood DT. Phylogeny and classification of the Digenea (Platyhelminthes: Trematoda). Int J Parasitol 2003; 33: 733-55. [CrossRef]

37. Gaevskaya AV, Gusev AV, Delyamure ES. Opredelitel Parazitov Pozvonochnueh Chernogo I Azovskogo Morei: Akademia Nauk Ukrainskoi CCP.; 1975. p. 550

38. Gaevskaya AV, Kovaleva AA. Spravochnik Osnovnykh Bolezney I Parazitov Promyslovykh Ryb Atlanticheskogo Okeana. Kaliningrad: Kaliningradskoe knizhnoe izd-vo 1991

39. Bartoli P, Gibson DI, Bray RA. Digenean species diversity in teleost fish from a nature reserve off Corsica, France (Western Mediterranean), and a comparison with other Mediterranean regions. J Nat Hist 2005; 39: 47-70. [CrossRef]

40. Linstow O. Compendium der Helminthologie Hanover1878. p.580

41. Eydal M, Bambir SH, Helgason S, editors. Bulletin of the Scandinavian Society For Parasitology Proceedings. 17 th Scandinavian Symposium of Parasitology June 15-17; University of Jyvaskyla, Finland. 1995.

42. Eydal M, Helgason S, Kristmundsson A, Bambir SH, editors. Metacercariae (Digenea) in Atlantic cod, haddock, whiting and saithe around Iceland. XIX Symposium Of The Scandinavian Society For Parasitology; May 8-11; Iceland: 1999.

43. Fischthal JH. Zoogeography of Digenetic Trematodes from West African Marine Fishes. Proceedings of The Helminthological Society of Washington. 1972; 39.

44. Bartoli P, Gibson DI. The occurrence of the Japanese species Dinosoma lophiomi Toman, 1973 (Digenea: Hemiuridae) in Lophius piscatorius (Teleostei) from the western Mediterranean. Syst Parasitol 2006; 65: 251-61. [CrossRef]

45. Manter HW. The digenetic trematodes of marine fishes of tortugas, Florida. Am Midl Nat. 1947; 38: 257-416. [CrossRef]

46. Bartoli P, Gibson DI. The status of Lecithochirium grandiporum (Rudolphi, 1819) (Digenea: Hemiuridae), a rarely reported and poorly known species from the Mediterranean moray eel Muraena helena L. in the Western Mediterranean. Syst Parasitol 2007; 68: 183-94. [CrossRef]

47. Looss A. Weitere Beiträge zur Kenntnis der Trematoden-Fauna Aegyptens, zugleich Versuch einer natürlichen Gliederung des Genus Distomum Retzius. Zoologische Jahrbücher: Abteilung für Systematik, Geographie und Biologie der Thiere 1899; 12: 521-784. [CrossRef]

48. Bartoli P, Gibson DI. Metadena phoceae n. sp. (Digenea: Cryptogonimidae), a rectal parasite of the shore rockling Gaidropsarus mediterraneus (Teleostei: Lotidae) in the western Mediterranean. Syst Parasitol. 2001; 50: 53-62. [CrossRef]

49. Linton E. Parasites of fishes of the Woods Hole region. Bull US Fish Comm 1901; 19: 405-92.

50. Leigh-Sharp WH. Calliobdella lophii, Van Beneden and Hesse. J Mar Biol Assoc UK. 1913; 10: 81-3. [CrossRef]

51. Kearn GC. Leeches, Lice and Lampreys. A natural history of skin and gill parasites of fishes. Netherlands: Springer; 2004.

52. Wilson CB. Parasitic Copepods taken during the third hancock expedition to the Galapagos Islands. in The University of Southern California Publications The Hancock Pacific Expeditions 1937. 